\title{
Ocorrência da Lixa-Grande do Coqueiro no Estado do Ceará
}

\author{
Francisco Marto P. Viana ${ }^{1}$, Cleilson N. Uchôa ${ }^{2}$, Francisco C. O. Freire ${ }^{1}$ \& Júlio C. Vidal ${ }^{1}$ \\ Embrapa Agroindústria Tropical, Cx. Postal 3761, CEP 60511-110, Fortaleza, CE, email: fmpviana@cnpat.embrapa.br ; \\ ${ }^{2}$ Centro de Ciências Agrárias, UFC, Cx. Postal 12168, CEP 60021-970, Fortaleza-CE
}

(Aceito para publicação em 27/07/2004)

Autor para correspondência: Francisco M. P. Viana

\begin{abstract}
Occurrence of coconut large verrucosis in the State of Ceará, Brazil

The occurrence of coconut (Cocos nucifera) large verrucosis is reported for the first time in producing areas of the State of Ceará, Brazil. The main symptoms of the disease are necrotic lesions on the folioles and petioles upon which many erumpent ascocarps are formed.
\end{abstract}

O coco (Cocos nucifera L.) brasileiro é uma das principais frutas da pauta nacional de exportações, tendo se tornado uma importante fonte de renda para a Região Nordeste, a qual tem aumentado a área plantada da variedade anão-verde, com o objetivo de atender o crescente mercado de água-decoco; bem como do coqueiro híbrido ou "anão-gigante", visando à produção de copra para suprir a demanda não coberta pelo coqueiro-gigante.

Desde meados de 2002, tem-se observado em cultivos comerciais de coqueiro anão-verde, bem como de coqueiro híbrido, em localidades dos municípios de Pacajus, Cascavel e Paraipaba, no Estado do Ceará, plantas com sintomas e sinais semelhantes aos da lixa-pequena, ou seja, seca das folhas associada à presença de estruturas rígidas na superfície dos folíolos (Figuras 1-A e 1-B). Entretanto, sob observação mais acurada verificou-se que esses sintomas e sinais divergem, em diversos aspectos, daqueles causados pelo agente da lixapequena. Apesar da doença similar a esta, ou seja, a lixa-grande, ainda não ter sido relatada no Estado do Ceará (Warwick, Doenças de fruteiras tropicais de interesse agroindustrial, Embrapa, 2003), coletaram-se folhas com sintomas, as quais foram conduzidas ao Laboratório de Fitopatologia da Embrapa Agroindústria Tropical, em Fortaleza, para análise. $\mathrm{O}$ exame macroscópico do material colhido revelou a presença de estruturas estromáticas maiores que aquelas produzidas pela lixa-pequena, e de coloração diferente, ou seja, marromacinzentada. Os estromas formavam pequenas rugas arredondadas e isoladas à superfície dos folíolos, concentrandose, principalmente, próximo à ráquis foliar e sobre a face superior desta. Na face inferior, encontraram-se apenas vestígios cicatriciais da presença do fungo. Ao contrário dos estromas produzidos pela lixa-pequena, estes estavam fracamente aderidos à superfície dos folíolos, podendo ser removidos com facilidade. Suspeitando-se que se tratasse da ocorrência de uma nova doença da cultura do coqueiro no Estado do Ceará, efetuaram-se cortes de tecidos afetados que, corados e observados ao microscópio óptico, revelaram a presença de ascostromas, originados no mesófilo, que rompiam a epiderme foliar quando maduros. Também, coletaram-se porções das referidas estruturas que, com auxílio de pistilo e almofariz esterilizados, contendo $2 \mathrm{ml}$ do corante azul de Amann, foram esmagadas para liberação das estruturas do microrganismo associado à doença. Em seguida, transferiu-se uma gota da suspensão obtida para uma lâmina de vidro para observação microscópica. As ascas, embora não evanescentes, eram diáfanas, contendo oito ascósporos unicelulares de coloração marrom-escura (Figura 1-C), medindo cerca de 22,5 X 13,5 $\mu \mathrm{m}$. Com base nos sintomas observados no campo e nos exames realizados aos microscópios estereoscópio e óptico, concluiu-se que o agente causal da doença é o fungo Sphaerodothis acrocomiae (Montagne) von Arx \& Müller (=Coccostroma palmicola (Speg.) von Arx \& Müller (CANNON, A revision of Phyllachora and some similar genera on the host family Leguminosae, CAB, 1991; ROGER. Encyclopédie micologique: Phytophatologie des pays chauds, Paul Lechevalier, 1953; Warwick et al., Doenças do coqueiro, Embrapa, 1997).

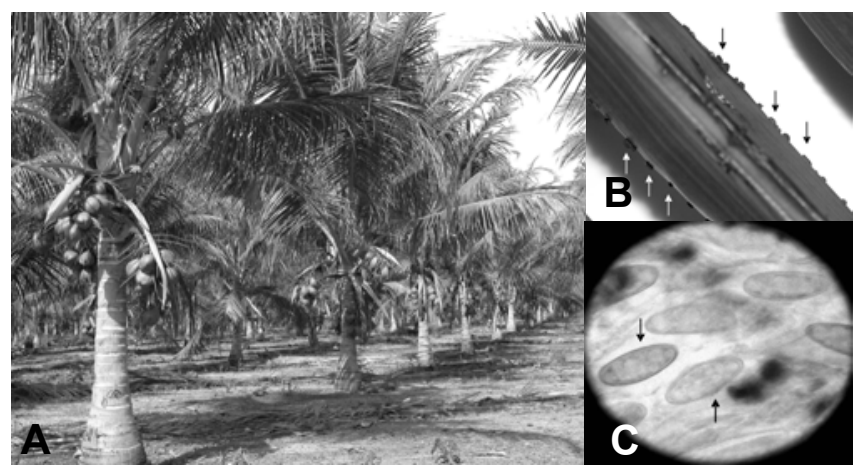

FIG. 1 - Sintomas típicos de lixa-grande em coqueiro (Cocos nucifera) híbrido: estromas na superfície do folíolo (A); manchas cicatriciais na face inferior do raque foliar (B); manchas iniciais na face superior do raque foliar (C); microfotografia de ascosporos de Sphaerodothis acrocomiae (D). 